\title{
Firm Characteristics and Speed of Adjustment : A Dynamic Panel Data Approach
}

\author{
Effulgence \\ Vol. 17, No. 2 \\ July - December 2019 \\ Rukmini Devi Institute of Advanced Studies \\ E-mail : effulgence@rdias.ac.in, Website : www.rdias.ac.in \\ http://effulgence.rdias.ac.in/user/default.aspx \\ https://dx.doi.org/10.33601/effulgence.rdias/v17/i2/2019/1-13
}

\section{Dr. Karamjeet Singh ${ }^{1}$ \\ Ms. Rajni ${ }^{2} \triangle$}

\begin{abstract}
The study attempts to inspect the influence of characteristics specific to firm on rate of adjustment speed towards optimal debt ratio. The study also tries to compare the rate of adjustment speed of under-levered and over-levered firms to analyze the asymmetries due to dissimilar debt position. The debt position is one of the major causes that could be the reason for asymmetry in the rate of adjustment speed. The study considers data set of 58 firms listed on BSE 100 index over nine years period (20092018) for analysis. The rich firm-level data over a period of nine years offers an ideal ground for rigorous empirical analysis. The study divides the sample into two groups under-levered and over-levered, and compared the rate of adjustment speed of these two types of firms. Arellano-Bover (AB)/Blundell-Bond (BB) dynamic panel data model (DPD) is used to measure the rate of adjustment speed to an optimal debt ratio. As per the findings, the adjustment speed of overall sample, under-levered and overlevered firms are $33 \%, 40 \%$, and $35 \%$ respectively. This implies that under levered firms adjust to their optimal debt ratio before over levered firms. Thus, the study partially validates the dynamic trade-off theory (DTT) of optimal capital structure in the emerging market firms, particularly Indian firms. One of the opportunities to perform better is the optimum utilization of capital. Balancing of capital structure is one of the biggest challenges. The researchers are therefore; keen to know why there are asymmetries in the rate of adjustment speed of firms so that firms can make early decisions to reduce the differences in actual debt ratio and optimal debt ratio to outperform. The study provides guidance to corporate managers to reform capital structure policy considering the effects of various firm-specific characteristics in India and other similar emerging market economies.
\end{abstract}

Keywords: Optimal capital structure, Rate of adjustment speed towards optimum debt ratio, Dynamic partial-adjustment model, Emerging economy.

1. Professor, University Business School, Panjab University, Chandigarh, krjsingh@gmail.com

2. Research Scholar, University Business School, Panjab University, Chandigarh, joshirajni.ubs@gmail.com 


\section{INTRODUCTION}

D o firms follow an optimal debt ratio? What are the factors affecting firms' optimal debt-ratio? What is the rate of adjustment speed of firms towards their optimal debt ratio? What are the factors affecting the rate of adjustment speed towards optimal leverage? Are different environment and different characteristics of a firm responsible for variability in the rate of adjustment speed? Capital structure research is now progressing towards finding the answers to these questions. Existing research examined the commonly known static trade-off model (STT) of capital structure which assumes firms must trade-off between benefits and marginal costs related to its decisions on capital structure. Graham and Harvey (2001) indicates that about $81 \%$ of Chief Financial Officer's (CFO) in their sample of 392 CFOs consider an optimal debt ratio or target range for deciding the proportion of debt-equity ratio by conducting a survey. When any company uses WACC while deciding the actual proportion of debt and equity, it presupposes the optimal capital structure presence (Brealy et al., 2014; Das Gupta, 2007). The factors that determine an optimal debt ratio is widely researched. But DTT model of capital structure highlighted the limitation of STT capital structure and documents that firms restructure their leverage ratio over time and speed at which firm tries to achieve target is dependent upon adjustment costs. In imperfect competition, such arguments need empirical validation due to wide implications in capital budgeting decisions. Lukos and Komera (2016) argue that varied adjustment cost is faced by the firms on account of complex asymmetric information. Adjustment cost includes transaction cost of issuing/ buyback debt or equity and implicit costs such as potential distress cost and marginal opportunity cost of not achieving the target rapidly. Nevertheless, other theories of capital structure, either pecking order hypothesis (POT) (Myers, 1984; Majluf \& Myers, 1984) or market timing theory (MTT) (Baker and Wurgler, 2002) both supports the evidence of snail adjustment speed towards target.
Majluf \& Myres (1984) upheld that the capital structure choices are made considering the ranking of various alternative sources of finance. The pecking order theory (POT) contends financing choices of firms based on asymmetric information cost, whereas Baker and Wurgler (2002) highlighted the decisions related to capital structure are significantly affected by the intensity of market. Welch (2004) contends that variability in debt ratio is influenced by the stock returns and their issuance activity explains an extensive extent of dynamism in the rate of adjustment speed. These theories don't believe in optimal debt ratio. The adjustment costs are different for different firms depending on their characteristics and financial motives.

There is a dearth of empirical literature in this direction in the emerging market specifically India. Except for the work of Ghose, 2017; Mukharjee and Mahakud, 2010. Ghose (2017) who investigated asymmetries in the rate of adjustment speed of group firms and standalone firms. This strand of literature, however, did not focus on the aspect of comparing the rate of adjustment speed of underlevered firms and over-levered firms. This study will investigate various firms' specific characteristics that can influence the leverage adjustment costs. Moreover, Indian firms are considered owing to complex information asymmetry problems, which exemplify the emerging market elsewhere in the world (Stiglitz, 1989; Khanna and Palepu, 2010). Indian capital market with its' underdeveloped regulatory and an institutional mechanism resemble capital markets elsewhere in the emerging economies.

Section 2 of the study will briefly examine the existing literature. Section 3 describes the sample selection process, data, and methods that are suitable for investigation and summary statistics. Empirical analysis of the study and discussion on the findings are presented in the 4th Section. Lastly, the5th section covers the conclusion of the study and recommended directions for future study. 


\section{REVIEW OF LITERATURE}

Most of capital structure research focusing on validating the STT model, POT (Myers\& ShyamSunder,1999) and MTT (Faulkender et al. (2012), but because of improvement in the panel data econometrics, the trend in capital structure is going towards empirically validating the DTT. The STT demonstrates that marginal advantages and costs are related to the issue of debt. Firms endeavor to tradeoff between the marginal advantages and costs of alternate finance choices and tries to achieve an optimal level of debt ratio. In a perfect market, the firm achieves an optimal debt ratio in no time. Empirical results point out that firms have an optimal debt ratio. Getzmann et al. (2014) on a sample of 1239 firms found significant evidence that firms in Asia pursue optimal capital structure. However, in an imperfect market the firms achieve an optimal debt ratio only if the adjustment benefits outweigh the adjustment cost; this is in line with the dynamic trade-off (DTT) model of capital structure as proposed by Fisher et al.1989. Recent research indicates that firms face the cost of adjusting to their optimal debt ratio. Fischer et al. (1989) predict the heterogeneity in the rate of adjustment speed towards optimal debt ratio in presence of firm specific adjustment costs. Studies that contravene the presence of target capital structure hypothesis are Majulf and Myres, 1984; Baker and Wurgler, 2002; Mazur, 2007.Rajan and Zingales (1995) revealed that institutional differences alone are not able to justify the variation in leverage adjustment. In contrary to this, Drobetz et al. (2015) compared the rate of adjustment speed of firms from bank based and market based nations and recorded that variation in the rate of adjustment speed towards optimal debt ratio is mainly attributable to the large variation in the cost of adjustment of the different financial system. Hovakimian et al. (2001) investigated the impact of macroeconomic risk on the various costs and advantages of adjusting towards the target and found that it affects the rate at which firms adjust. Similar results were found by Amjed and Shah, 2016 and Memon et al, 2015. Byoun (2008) reported that when firms confront financial deficit/ surplus they move toward the optimal capital structure but not in accordance with traditional pecking order theory. Smith et al. (2015) found similar results. Faulkender et. al. (2012) investigated the considerable effects of free cash flows on the rate of adjustment speed. Zhou et al. (2016) found very strong evidence on the positive impact of the rate of adjustment speed on the cost of equity capital (COE). Tahir et al.(2016) provide the direct evidence of the speed toward target capital structure and dividend policy of family-owned business and indicated that family owned businesses rebalance their target capital structure with higher speed $(38.70 \%)$ than nonfamily owned businesses. Ahsan et al., (2016) empirically examined the dynamic trade off hypothesis of firms listed in Pakistan on a sample of 13375 non-financial firms for the time of 1972-2010 over the life cycle. The study revealed low-high-low debt-equity ratio pattern during growth, maturity and decline stage. Tian et al.(2015) found the same results but the study classified firms for different stages of their life cycle on the basis of cash flows. Tsoy and Heshmanti (2017) have tried to examine the effects of adverse financial crisis on speed of adjustment of capital structure towards targeted level of debt. The authors considered 1159 Korean listed firms as a sample for a period of 1985-2015. The authors reported 9.4 percent speed of adjustment. The authors found a strong negative effect and a positive effect on speed of adjustment of Asian financial crisis 1997 and Global Financial crisis 2008 respectively. Kannadhasan et al. (2018) examined which theory is superior in the context of China, India and South Africa for the time span of 1996-2016. The results substantiated that STT is better than other theories of capital structure.

Previous studies have used different methods to consistently estimate the speed of adjustment. Titman and Wessels (1988) applied panel regression model with OLS estimation. Cook and Tang (2010) applied GMM estimation technique Improvement in the econometrics leads to the application of dynamic partial adjustment framework in capital structure 
research. Because of this reason, different studies reported varied estimates of the rate of adjustment speed. Flannery and Rangan (2006) reported firms to change its debt ratio in accordance with target debt ratio at a rate beyond $30 \%$ in the US. Antoniou et al.(2008) reported rate of adjustment for firms in the US \&UK is $32 \%$ and France is 39\%. Getzmann et al. (2010) found that Asian firms adjust at around 27\% to $39 \%$ towards their optimal debt ratio. Mukherjee and Mahakud (2010) reported 33\% rate per year at which firms adjust towards optimal capital structure in India. Drobetz et al. (2015) estimated 25\% speed of adjustment per year for firms from G-7 countries. Ataunal and Aybars (2017) estimated 44\% adjustment speed per year of Bosra Istanbul firms'(BIST).These results clearly show that firms facing a lower cost of adjustment adjust more rapidly than firms facing a higher cost of adjustment.

When we look at the literature, previous studies are not likely to give precise estimates of the varied rates of adjustment speeds in the emerging market like India as Lukos and Komera (2016) argue that varied adjustment cost is faced by the firms on account of complex asymmetric information. Several firmspecific characteristics that depict their ability to raise finance can help to explain changes in speed of adjustment. Chang el al. (2014) provided evidence that both under-levered and over levered Chinese Listed firms adjust slowly to the optimal debt ratio. However, the limitation of this study is that the study considered inefficient corporate governance firms. In this way, the current examination endeavors to look at the influence of various firms' specific characteristics on the rate of adjustment speed towards optimal debt ratio of Indian listed firms. The current study divides the sample into two groups: over levered firms and under levered firms and compares the speed of adjustment of these two types of firms.

\section{DATA COLLECTION AND METHODOLOGY}

The study selects BSE 100 index firms. The criteria for selection of BSE-100 index companies were because of its:

i. Wide coverage of both specified and non specified list of companies

ii. Market activity

iii. Liquidity

iv. Due representation given to the various industrial groups

Indian corporate are chosen to investigate the influence of various characteristics of firm on rate of adjustment speed because of underdeveloped institutional mechanism and its weaker investor activism, India is more prone to complex asymmetric information problem. (Stiglitz, 1989; Khanna \& Palepu, 2010).When the capital market is perfect, the optimal ratio and actual ratio of debt of the firms are same. Unlike Perfect market, firm tends to depart from their optimal debt ratio and hence desires to achieve targets. These deviations and firms' intensity to achieve these targets are measured through rate of adjustment speed. This makes Indian corporate an ideal testing ground for rigorous empirical analysis.

All the required information has been taken from 'Capitaline plus' Database. The examination time frame is from 2009 to 2018. The original data was collected for 100 firms. This dataset has been subject to certain filters (Rajan and Zingales, 1995; Mukharjee, 2010). All companies with missing observation for any time period have been deleted. The study also excludes financial firms. It is a balanced panel dataset with a final testable dataset of 58 firms with 522 observations. Table 1 presents the detailed description of the considered variables and the expected relationship of these variables with debt. 
Table 1: Variables Description

\begin{tabular}{|c|c|c|c|c|}
\hline Variables & $\begin{array}{l}\text { Type of } \\
\text { Variable }\end{array}$ & Definition & Studies & $\begin{array}{l}\text { Expected } \\
\text { Relationship as } \\
\text { per POT and TOT }\end{array}$ \\
\hline Debt Ratio(LEV) & $\begin{array}{l}\text { Dependent } \\
\text { Variable }\end{array}$ & $\begin{array}{l}\text { Total debt / } \\
\text { Total assets }\end{array}$ & $\begin{array}{l}\text { Fisher et al. 1989, Chaklader } \\
\text { \& Jaisinghani, } 2017\end{array}$ & \\
\hline Size & $\begin{array}{l}\text { Explanatory } \\
\text { Variable }\end{array}$ & $\begin{array}{l}\text { Natural Log of } \\
\text { total assets }\end{array}$ & $\begin{array}{l}\text { Fisher et al. 1989,Chaklader } \\
\text { \& Jaisinghani, 2017; } \\
\text { Ghose,2017 }\end{array}$ & $\begin{array}{l}\text { POT (-ve) } \\
\text { TOT (+ve) }\end{array}$ \\
\hline Tangibility(TANG) & $\begin{array}{l}\text { Explanatory } \\
\text { Variable }\end{array}$ & $\begin{array}{l}\text { Net block/ Total } \\
\text { assets }\end{array}$ & Myres, 1984; Basu,2015 & $\begin{array}{l}\text { POT (-ve) } \\
\text { TOT (+ve) }\end{array}$ \\
\hline Profitability(PROF) & $\begin{array}{l}\text { Explanatory } \\
\text { Variable }\end{array}$ & $\begin{array}{l}\text { EBIT as a } \\
\text { proportion of } \\
\text { sales }\end{array}$ & $\begin{array}{l}\text { Fama and } \\
\text { French, 2002; Jaisinghani, } \\
\text { 2017; }\end{array}$ & $\begin{array}{l}\text { POT (-ve) } \\
\text { TOT (+ve) }\end{array}$ \\
\hline $\begin{array}{l}\text { Non-Debt Tax } \\
\text { Shield(/NDTS) }\end{array}$ & $\begin{array}{l}\text { Explanatory } \\
\text { Variable }\end{array}$ & $\begin{array}{l}\text { Depreciation / } \\
\text { Net sales }\end{array}$ & Ghose, 2017 & TOT (+ve) \\
\hline $\mathrm{M} / \mathrm{B}$ ratio & $\begin{array}{l}\text { Explanatory } \\
\text { Variable }\end{array}$ & $\begin{array}{l}\text { Market / Book } \\
\text { value of assets }\end{array}$ & Ghose, 2017 & $\begin{array}{l}\text { Negative } \\
\text { Relationship }\end{array}$ \\
\hline Uniqueness & $\begin{array}{l}\text { Explanatory } \\
\text { Variable }\end{array}$ & $\begin{array}{l}\text { Ratio of selling } \\
\text { expenses to net } \\
\text { sales }\end{array}$ & Ghose, 2017 & $\begin{array}{l}\text { Negative } \\
\text { Relationship }\end{array}$ \\
\hline Age & $\begin{array}{l}\text { Explanatory } \\
\text { Variable }\end{array}$ & $\begin{array}{l}\text { Current year- } \\
\text { establishment } \\
\text { year }\end{array}$ & Jaisinghani, 2017 & $\begin{array}{l}\text { POT (-ve) } \\
\text { TOT (+ve) }\end{array}$ \\
\hline Liquidity(LIQ) & $\begin{array}{l}\text { Explanatory } \\
\text { Variable }\end{array}$ & $\begin{array}{l}\text { Current assets/ } \\
\text { Current Liability }\end{array}$ & Jaisinghani, 2017 & $\begin{array}{l}\text { POT (-ve) } \\
\text { TOT }(+v e)\end{array}$ \\
\hline
\end{tabular}

The optimal debt ratio (Leverage*) is estimated using the following model,

Leverage $^{*}=\propto \mathrm{X}_{i, t}$

Wherein $X_{i, t}$ are the important determinants of optimal debt ratio, namely, size, profitability, tangibility, NDTS, M/B, uniqueness, age and liquidity. Thereafter, firms were divided into underlevered and over-levered firms. Optimal debt ratio was estimated using model (1).

When the market is perfect the observed leverage and optimal leverage are equal. Because of market imperfection, observed leverage tends to depart from the optimal leverage. Thereafter, average of optimal debt ratio and actual debt ratio is calculated using 09 years of data. If average of actual exceeds average of optimal debt ratio, the firms is considered as over-levered and if average of actual debt ratio is less than average of optimal debt ratio, the firms is considered as under-levered.

Rate of adjustment speed is calculated using the following equation

Leverage $_{i, t}-$ Leverage $_{i,-1}=\rho\left(\right.$ Leverage $_{i, t}^{*}-$ Leverage $\left._{i,-1}\right)$ 
Leverage* represents the optimal debt ratio and $p$ represents the rate of adjustment speed. Equation 2 can also be rearranged as given:

Leverage $_{i, t}=\rho\left(\right.$ Leverage $\left._{i, t}^{*}\right)+(1-\rho) *$ Leverage $\left._{i, t-1}\right)$

The optimal debt ratiois estimated using the below equation:

Leverage $^{*}=\propto X_{i, t}$

Equation (2) and (3) can be presented as:

Leverage $_{\mathrm{i}, t}=\delta^{*}$ Leverage $_{\mathrm{i},-1-1}+\rho^{*} \propto \mathrm{X}_{\mathrm{i},-1-1}$

The equation can be written by incorporating all the firm specific variables as:

Leverage $_{\mathrm{i}, t}=\delta^{*}$ Leverage $_{\mathrm{i}, t-1}+\rho^{*} \propto$ SSize $_{\mathrm{i}, \mathrm{t}-1}+\rho^{*} \propto 2$ tang $_{\mathrm{i}, \mathrm{t}-}$ ${ }_{1}+\rho^{*} \propto 3 \operatorname{prof}_{\mathrm{i}, \mathrm{t}-1}+\rho^{*} \propto 4 \mathrm{NDTS}_{\mathrm{i}, \mathrm{t}-1}+\rho^{*} \propto 5 \mathrm{M} / \mathrm{B}_{\mathrm{i}, \mathrm{t}-}$

${ }_{1}+\rho^{*} \propto 6 \mathrm{UNIQ}_{\mathrm{i}, \mathrm{t}-1}+\rho^{*} \propto 7 \mathrm{LIQ}_{\mathrm{i},-1}$

The rate of adjustment speed is given by $1-\delta=\rho$. The higher the estimation of $\delta$, the lower is the rate of adjustment speed. In model (5), Leverage $e_{i, t}$ is a dependent variable and Leverage $_{\mathrm{i},-1}$ is an independent variable. The panel model with dependent variable as lagged variable suffers from two major shortcomings. First, there is presence of auto correlation in the equation and presence of individual fixed effect (Batlagi, 2008). In case of fixed effect estimation, the lagged dependent variable coefficient when acts as andependent variable is biased upward with the application of instrumental variable estimation, because of violation of strict erogeneity problem. Arellano and Bond in the year 1991 devised a method that is based upon generalized methods of moments (GMM) estimation.
Therefore, the study has used Arellano and Bond method to calculate the rate of adjustment speed based upon generalized methods of moments. The other firm specific variables are also incorporated into the model to observe their impact on rate of adjustment speed towards optimal debt ratio.

Further, in order to avoid any form of contemporaneous correlation, one year prior figures of the independent variables are examined in the final DPD model. A host of past studies have used this technique (Badinger et al., 2004; Chaklader and Jaisinghani, 2016). The study also tries to compare the rate of adjustment speed of under-levered and over-levered firms in order to find the asymmetries because of dissimilar debt position.

Thus, the study hypothesized that there is no differences in the rate of adjustment speed of over levered and under levered firms. This hypothesis is tested by estimating the rate of adjustment speed of under levered and over levered firms separately.

\section{EMPIRICAL RESULTS OF THE STUDY}

\section{Summary Statistics}

Table 2 represents the relevant descriptive statistics for firms listed in BSE 100 index, over levered and under levered firms covering a 09 years period, 200910 to 2017-18.The average debt as a proportion to total assets is around 0.97 for all the firms, 0.98 for over levered and 0.95 for under levered firms.

Table 2: Summary Statistics

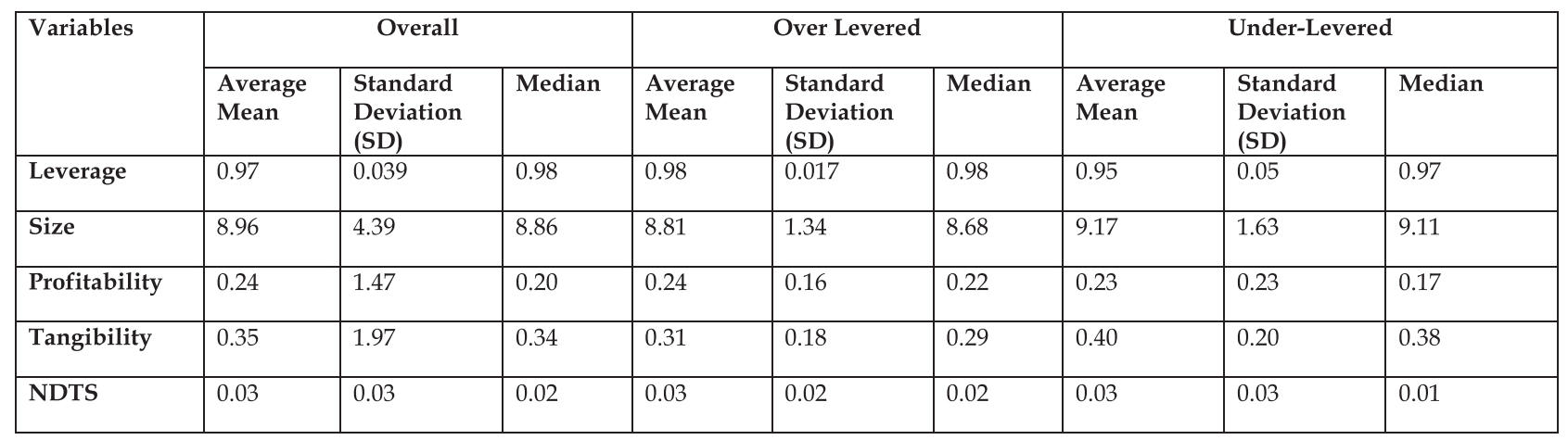




\begin{tabular}{|l|l|l|l|l|l|l|l|l|l|}
\hline MB Ratio & 0.35 & 0.33 & 0.25 & 0.31 & 0.32 & 0.21 & 0.41 & 0.34 & 0.32 \\
\hline Uniqueness & 0.16 & 0.23 & 0.10 & 0.14 & 0.15 & 0.10 & 0.20 & 0.31 & 0.09 \\
\hline Age & 3.65 & 0.56 & 3.66 & 3.52 & 0.54 & 3.46 & 3.86 & 0.53 & 4.05 \\
\hline Liquidity & 2.56 & 2.58 & 1.88 & 3.11 & 3.11 & 2.33 & 1.74 & 0.99 & 1.45 \\
\hline
\end{tabular}

Source : 'Capitaline Plus' Database, Statistical Tool: Eviews 13

Table 2 represents the average mean, standard deviation (SD) and median of the independent and dependent variables considered in the study. The variables include leverage, size, profitability, tangibility, NDTS, M/B, uniqueness, age and liquidity. Results show that median and mean of leverage is more for over levered relative to under levered firms.

\section{Correlation}

Table 3: Correlations

\begin{tabular}{|c|c|c|c|c|c|c|c|c|c|}
\hline & LEV & AGE & LIQ & MB & NDTS & PROFI & SIZE & TANGI & $\begin{array}{c}\text { UNIQUE } \\
\text { NESS }\end{array}$ \\
\hline LEV & 1.000000 & & & & & & & \\
\hline AGE & 0.188781 & 1.000000 & & & & & & \\
\hline LIQ & 0.097187 & -0.057931 & 1.000000 & & & & & \\
\hline MB & 0.174314 & 0.194771 & -0.058717 & 1.000000 & & & & \\
\hline NDTS & 0.072205 & -0.155135 & -0.065969 & 0.142487 & 1.000000 & & & \\
\hline PROF & -0.277484 & -0.002478 & 0.065176 & -0.399814 & -0.279190 & 1.000000 & & \\
\hline SIZE & 0.322926 & 0.201713 & 0.013380 & 0.499717 & 0.261150 & -0.430043 & 1.000000 & & \\
\hline TANG & -0.269572 & -0.122230 & -0.370235 & -0.010916 & 0.168078 & 0.148277 & -0.116767 & 1.000000 & \\
\hline $\begin{array}{c}\text { UNIQUE } \\
\text { NESS }\end{array}$ & -0.342053 & 0.041071 & -0.182783 & -0.312337 & -0.181544 & 0.734848 & -0.529115 & 0.304485 & 1.000000 \\
\hline
\end{tabular}

Source: 'Capitaline Plus' Database, Statistical Tool: Eviews 13

Results of correlation are presented in Table 3. The variables include lev, size profitability, tangibility, NDTS, M/B, uniqueness, age and liquidity. It is evident from the table that the multicollinearity between the variables is not alarming. None of the pair has correlation of more than 0.8 . Hence, data does not suffer from problem of multicollinearity.

\section{Results of tests of stationarity}

Levin-Lin-chu (LLC) and (PP-Fischer) tests are performed with the aim to check the stationarity of all the variables considered in the study. The null hypothesis states that unit root is present in the variables (dependent and independent) and the data is not stationary when in its base form. For further analysis, the null hypothesis should be rejected. The results clearly indicate that the null hypothesis is rejected as P-Value is less than $10 \%$.

Result of stationarity is presented in Table 4. The rejection of null hypothesis states that the variables (dependent and independent) do not have a unit root and are stationary. The variables include lev, size, profitability, tangibility, NDTS, M/B, uniqueness, age and liquidity. ${ }^{* *}$ and ${ }^{*}$ show that the hypothesis is significant at 0.05 and 0.10 levels respectively. 
Table 4: Results of Stationarity

\begin{tabular}{|c|l|l|l|l|}
\hline Variable & LLC & p-Value & PP-Fischer & p-Value \\
\hline LEV & $-36.260^{* *}$ & 0.00 & $490.412^{* *}$ & 0.00 \\
\hline AGE & $-43.4619^{* *}$ & 0.00 & $1068.40^{* *}$ & 0.00 \\
\hline LIQ & $-3.83287^{* *}$ & 0.00 & $212.971^{* *}$ & 0.00 \\
\hline MB & $-4.9586^{* *}$ & 0.00 & $243.178^{* *}$ & 0.00 \\
\hline NDTS & $-7.69451^{* *}$ & 0.00 & $182.858^{* *}$ & 0.00 \\
\hline PROF & $-9.90377^{* *}$ & 0.00 & $204.084^{* *}$ & 0.00 \\
\hline SIZE & $-12.3857^{* *}$ & 0.00 & $368.632^{* *}$ & 0.00 \\
\hline TANG & $-4.01219^{* *}$ & 0.00 & $234.836^{* *}$ & 0.00 \\
\hline UNIQUENESS & $-5.64813^{* *}$ & 0.00 & $217.113^{* *}$ & 0.001 \\
\hline
\end{tabular}

Source: 'Capitaline Plus' Database, Statistical Tool: Eviews 13

\section{Results of Dynamic Panel Regression}

Section 5.3 highlights the results of the regression estimates of overall sample, under levered firms and over levered firms. The regression results are based on GMM estimation methodology applied by Arellano and Bond (A \& B, 1991). The estimated coefficients of a model along with their standard errors, t-statistics and p-values are presented in panel A. The table highlights that the estimated coefficient of the lagged term of LEV is 0.67 . Further, the coefficient of lagged term of debt ratio is also significant at $10 \%$ level of significance. The rate of adjustment speed is estimated as one minus $\mathrm{p}$. The rate of adjustment speed of Indian firms is $33 \%$. This indicates that firms in India are moving towards target leverage.

Table 5: Results of Dynamic Panel Regression (Overall)

\begin{tabular}{|c|c|c|c|c|}
\hline \multicolumn{5}{|c|}{ PANEL A : REGRESSION ESTIMATES } \\
\hline \multirow{2}{*}{ Variables } & Coefficient & Prob. & t-Statistic & Std. Error \\
\hline LEV(-1) & $0.671393^{* *}$ & 0.0000 & 69.43854 & 0.009669 \\
\hline AGE(-1) & $-0.054110^{* *}$ & 0.0000 & -13.31536 & 0.004064 \\
\hline LIQ(-1) & 0.000257 & 0.2556 & 1.137926 & 0.000226 \\
\hline MB(-1) & $-0.007668^{* *}$ & 0.0000 & -10.73444 & 0.000714 \\
\hline NDTS(-1) & $-0.094207^{* *}$ & 0.0000 & -5.365830 & 0.017557 \\
\hline PROF(-1) & $-0.027842^{* *}$ & 0.0000 & -16.30576 & 0.001707 \\
\hline SIZE(-1) & $0.011739^{* *}$ & 0.0000 & 21.33025 & 0.000550 \\
\hline TANG(-1) & $-0.001590^{* *}$ & 0.0009 & -3.331829 & 0.000477 \\
\hline UNIQUENESS(-1) & $0.034280^{* *}$ & 0.0000 & 47.69287 & 0.000719 \\
\hline J-statistics & 0.596181 & & \\
\hline
\end{tabular}

\begin{tabular}{|c|c|c|}
\hline \multicolumn{2}{|c|}{ PANEL B: RESIDUAL DIAGNOSTICS } \\
\hline Order of test & M-Statistic & Probability \\
\hline $\mathrm{AR}(1)$ & -1.724870 & 0.0846 \\
\hline $\mathrm{AR}(2)$ & 0.518741 & 0.6039 \\
\hline
\end{tabular}

Source: 'Capitaline Plus' Database, Statistical Tool: Eviews 13

In Table 5 of panel A reports the results of regression estimates of overall firms. Liquidity is not statistically significant at any level of significance.
Age is found to be associated with debt ratio and the association is negative. This implies that older firms having low leverage. Size and uniqueness is 
positively related with the proportion of debt equity. J-statistics is found to be insignificant, hence the model is valid.

The results of residual diagnostic care reported on Panel B of Table 5. The assumptions of Dynamic
Panel model clearly states that the errors should follow $\mathrm{AR}(1)$ and do not follow $\mathrm{AR}(2)$ as given by Arellano and bond(1991). As AR(1) is significant at $10 \%$ level, one order autocorrelation follows and $\mathrm{AR}(2)$ is insignificant, which means second order correlation does not follow.

Table 6: Results of Dynamic Panel Regression (Over levered)

\begin{tabular}{|c|c|c|c|c|}
\hline \multicolumn{5}{|c|}{ PANEL A : REGRESSION ESTIMATES } \\
\hline Variable & Coefficient & Prob. & t-Statistic & Std. Error \\
\hline LEV(-1) & $0.653532^{* *}$ & 0.0000 & 35.01145 & 0.018666 \\
\hline AGE(-1) & $0.011448^{* *}$ & 0.0003 & 3.642415 & 0.003143 \\
\hline LIQ(-1) & $-0.000211^{* *}$ & 0.0511 & -1.957010 & 0.000108 \\
\hline MB(-1) & $-0.000629^{* *}$ & 0.0227 & -2.287968 & 0.000275 \\
\hline NDTS(-1) & $-0.060596^{* *}$ & 0.0000 & -6.281480 & 0.009647 \\
\hline PROF(-1) & 0.002811 & 0.1221 & 1.549690 & 0.001814 \\
\hline SIZE(-1) & -0.000492 & 0.4285 & -0.792613 & 0.000621 \\
\hline TANG(-1) & $0.003404^{* *}$ & 0.0001 & 3.890888 & 0.000875 \\
\hline UNIQUENESS(-1) & $0.009847^{* *}$ & 0.0000 & 4.230205 & 0.002328 \\
\hline
\end{tabular}

\begin{tabular}{|c|c|c|}
\hline \multicolumn{3}{|c|}{ PANEL B : RESIDUAL DIAGNOSTICS } \\
\hline Order of test & m-Statistic & Probability \\
\hline $\mathrm{AR}(1)$ & -0.014834 & 0.0882 \\
\hline $\mathrm{AR}(2)$ & 0.004875 & 0.9961 \\
\hline J-Statistic & 23.38 & \\
\hline
\end{tabular}

Source: 'Capitaline Plus' Database, Statistical Tool: Eviews 13

Results of dynamic panel regression of over-levered firms are shown on Panel A of Table 6. The explanatory variables include Lev, Size, profitability, tangibility, NDTS, M/B, uniqueness, age and liquidity. The rate of adjustment speed of over levered firms is $35 \%$ (1- $0.65 \%$ ). Profitability and size are insignificantly associated with the leverage of over levered firms. Age is positively associated with the leverage at 0.05 level of significance. It implies that old firms having the high leverage, which is contrary to overall results. M/B ratio, LIQ and NDTS are negatively associated with capital structure at conventional levels. Tangibility has positive significant impact on debt ratio of the over levered firms. This supports the validity of tradeoff theory of the capital structure. The J - statistics is insignificant, the model is valid.

Result of residual diagnostic is presented in Table 7 of Panel B. As AR(1) is significant at $10 \%$ level, one order autocorrelation follows and $\operatorname{AR}(2)$ is insignificant, which means second order correlation does not follow. This concludes that overall model is valid. 
Table 7: Results of Dynamic Panel Regression (Under levered)

\begin{tabular}{|c|c|c|c|c|}
\hline \multicolumn{5}{|c|}{ PANEL A : REGRESSION ESTIMATES } \\
\hline Variable & Coefficient & Prob. & t-Statistic & Std. Error \\
\hline LEV(-1) & $0.602016^{* *}$ & 0.0000 & 9.622519 & 0.062563 \\
\hline AGE(-1) & $-0.060114^{* *}$ & 0.0969 & -1.666447 & 0.036073 \\
\hline LIQ(-1) & -0.002426 & 0.1716 & -1.371150 & 0.001769 \\
\hline MB(-1) & $-0.020380^{* *}$ & 0.0000 & -4.828203 & 0.004221 \\
\hline NDTS(-1) & -0.228495 & 0.1446 & -1.463675 & 0.156111 \\
\hline PROF(-1) & $-0.055072^{* *}$ & 0.0000 & -5.380714 & 0.010235 \\
\hline SIZE(-1) & $0.017454^{* *}$ & 0.0000 & 4.983654 & 0.003502 \\
\hline TANG(-1) & $-0.013320^{* *}$ & 0.0193 & -2.355793 & 0.005654 \\
\hline UNIQUENESS(-1) & $0.063497^{* *}$ & 0.0000 & 8.425185 & 0.007537 \\
\hline J-statistics & 20.70 & & & \\
\hline
\end{tabular}

\begin{tabular}{|c|c|c|}
\hline \multicolumn{3}{|c|}{ PANEL B: RESIDUAL DIAGNOSTICS } \\
\hline Test order & m-Statistic & Probability \\
\hline $\mathrm{AR}(1)$ & & 0.0350 \\
\hline $\mathrm{AR}(2)$ & -0.208237 & 0.970 \\
\hline
\end{tabular}

Source: 'Capitaline Plus' Database, Statistical Tool: Eviews 13

Results of dynamic panel regression of underlevered firms are shown on Panel A of Table 7.The explanatory variables include Lev, Size, profitability, tangibility, NDTS, M/B, uniqueness, age and Liquidity. The rate of adjustment speed of under levered firms is $40 \%$ (1- $0.60 \%)$. Liquidity and NDTS are insignificantly associated with the debt ratio of over levered firms. Age is negatively associated with the capital structure at 0.05 levels. Tangibility (TANGI), Market to book (M/B) value, profitability is negatively associated with capital structure at conventional levels. This follows the pecking order (POT) hypothesis of the capital structure. The J statistics is found to be insignificant, it means the model is valid.

The residual diagnostics are reported in the Panel B of Table 7 and result shows that $\mathrm{AR}(1)$ is significant at $10 \%$ level, one order autocorrelation follows and $\mathrm{AR}(2)$ is insignificant, which means second order autocorrelation does not follow. This concludes that overall dynamic panel model is valid and results are also reliable.

\section{DISCUSSIONSAND CONCLUSION}

In the current study, according to the debt position of a firm, the firms are classified into under levered and over levered firms. To examine the dynamic nature of the capital structure, rate of adjustment speed towards optimal debt ratio is calculated. The analysis has been carried out for companies listed in BSE 100 index. A final sample consists of 58 firms consist of 35 over levered and 23 under levered firms. A 09 - year frame has been considered for estimating the results. Dynamic Panel regression methodology through the application of Arellano and Bond (1991) model has been applied to estimate the rate of adjustment speed towards optimal debt ratio.

The results clearly show that the rate of adjustment 
speed of under-levered firms is notably higher compared to over-levered firms. The probable reason could be, under levered firms have more debt capacity and better financing opportunities. However, overall speed of adjustment is $30 \%$, which is very low relative to other nations such as UK, France and Spain. Ozkan, 2001, reported 59\% rate of adjustment speed of UK firms, Miguel \& Pindado, 2001 , documented $80 \%$ rate of adjustment speed of Spain firms and Antoniou et. al., 2008, reported 39\% rate of adjustment speed of France firms. This may be because of intrinsic barriers of obtaining external financing (Allen et al., 2012) which leads to higher adjustment cost and lesser potential benefits.

The results bear important implications for manager and regulators, as managers must identify the barriers involved in achieving optimal debt ratio and promote the growth necessary for the survival of the firms. And regulators should devise policies that can help firms to modify their existing capital structure by making financial institution more accountable and autonomous. Such actions would turn down the cost of capital and making Indian listed firms more productive and competitive.

The limitations of the current study is that it did not consider marked based measure to calculate leverage, due to unavailability of market based data of firms. The current study was conducted in India only, thus further insights can be obtained by considering other emerging markets.

\section{REFERENCES}

1) Allen, F., Chakrabarti, R., De, S. and Qian, M. (2012), "Financing firms in India", Journal of Financial Intermediation, 21(3), 409-445.

2) Amjed, S., \& Amir Shah, S. M. (2016), "The Impact of Volatile Economic Conditions on Corporate Capital Structure Adjustment towards Dynamic Target in Pakistan", Pakistan Journal of Commerce \& Social Sciences, 10(2).

3) Arellano, M., \& Bover, O.(1995), “Another look at the instrumental variable estimation of error- components models", Journal of econometrics, 68(1), 29-51.

4) Ataünal, L., \&Aybars, A. (2017), “Testing TargetAdjustment and Pecking Order Models of Capital Structure and Estimating Speed of Adjustment: Evidence from Borsa Istanbul (BIST)", International Journal of Corporate Finance and Accounting (IJCFA), 4(1), 1-15.

5) Badinger, H., Muller, W. and Tondl, G. (2004), "Regional convergence in the European Union, 1985-1999: a spatial dynamic panel analysis", Regional Studies, 38(3), 241-253.

6) Baltagi, B. (2008), "Econometric Analysis of Panel Data", John Wiley and Sons, London, UK.

7) Byoun, S. (2008), "How and when do firms adjust their capital structures toward targets?", The Journal of Finance, 63(6), 3069-3096.

8) Chaklader, B., \& Jaisinghani, D. (2017), “Testing dynamic trade off theory of capital structure: an empirical study for the textile industry in India and China", Afro- Asian J. Finance and Accounting. 7(4).

9) Chang, Y. K., Chou, R. K., \& Huang, T. H. (2014), "Corporate governance and the dynamics of capital structure: New evidence", Journal of Banking \& Finance, 48, 374-385.

10) Cook, D. O., \& Tang, T. (2010), “Macroeconomic conditions and capital structure adjustment speed", Journal of corporate finance, 16(1), 73-87.

11) Cook, D. O., \& Tang, T. (2010), “Macroeconomic conditions and capital structure adjustment speed", Journal of corporate finance, 16(1), 73-87.

12) Das, S. (2012), "The role of leverage and stockbased variables in the prediction of cash flows and earnings - some evidence from India", AfroAsian Journal of Finance and Accounting, 3(1), 144.

13) Fama, E. F., \& French, K. R. (2002), "Testing trade-off and pecking order predictions about dividends and debt", The Review of Financial Studies, 15(1), 1-33.

14) Fama, E. F., \& French, K. R. (2002), "Testing trade-off and pecking order predictions about dividends and debt", The Review of Financial Studies, 15(1), 1-33. 
15) Faulkender, M., Flannery, M., Hankins, K., Smith, J., 2008, “Do adjustment costs impede the realization of target capital structure? Working Paper.

16) Fischer, E. O., Heinkel, R., \& Zechner, J. (1989), "Dynamic capital structure choice: Theory and tests", The Journal of Finance, 44(1), 19-40.

17) Flannery, M. J., \& Rangan, K. P. (2006),“Partial adjustment toward target capital structures", Journal of Financial Economics, 79(3), 469-506.

18) Getzmann, A., Lang, S., \& Spremann, K. (2010), "Determinants of the target capital structure and adjustment speed-evidence from Asian capital markets", European Financial Management Symposium.

19) Getzmann, A., Lang, S., \& Spremann, K. (2014), "Target capital structure and adjustment speed in Asia", Asia-Pacific Journal of Financial Studies, 43(1), 1-30.

20) Ghose (2017), "Impact of Business Group Affiliation on capital structure adjustment speed: Evidence from Indian manufacturing sector", Emerging Economy Studies, 3(1), 54-67.

21) Graham, J. R., \& Harvey, C. R. (2001), “The theory and practice of corporate finance: Evidence from the field", Journal of financial economics, 60(2), 187-243.

22) Hovakimian, A., Opler, T., \& Titman, S. (2001), "The debt-equity choice", Journal of Financial and Quantitative analysis, 36(1), 1-24.

23) Jaisinghani, D. (2016), “Group affiliation, R\&D and firm performance: empirical evidence from Indian manufacturing sector", International Journal of Business and Emerging Markets, 8(1), 30-48.

24) Kannadhasan, M., Thakur, B. P. S., Gupta, C. P., \& Charan, P. (2018). “Testing capital structure theories using error correction models: Evidence from China, India, and South Africa", Cogent Economics \& Finance, 6(1), 1443369.

25) Khanna,T., \& Palepu, K. (1997), “Why focused strategies may be wrong for emerging markets", Harvard business review, 75(4), 41-48.

26) Komera, S., \& JijoLukose, P. J. (2016), "Heterogeneity and Asymmetry in Speed of
Leverage Adjustment: The Indian Experience", Review of Pacific Basin Financial Markets and Policies, 19(03).

27) Mazur, K. (2007). “The determinants of capital structure choice: evidence from Polish companies", International Advances in Economic Research, 13(4), 495-514.

28) Memon, P. A., MdRus, R., \& Ghazali, Z. (2015), "Dynamism of capital structure: Evidence from Pakistan", Journal of International Business and Economics.

29) Miguel, A. D., \& Pindado, J. (2001), "Determinants of capital structure: New evidence from Spanish panel data", Journal of Corporate Finance. 7, 77-99.

30) Miller, M. H., \& Modigliani, F. (1966), "Some estimates of the cost of capital to the electric utility industry", The American Economic Review, 56(3), 333-391.

31) Miller, M. H., \& Modigliani, F. (1966), "Some estimates of the cost of capital to the electric utility industry, 1954-57", The American Economic Review, 56(3), 333-391.

32) Modigliani, F., \& Miller, M. H. (1963), "Corporate income taxes and the cost of capital: a correction", The American economic review, 433-443.

33) Modigliani, F., \& Miller, M. H.(1958), “The Cost of Capital, Corporation Finance and the Theory of Investment", The American Economic Review, 48(3), 261-297.

34) Mukherjee, S., \&Mahakud, J. (2010), “Dynamic adjustment towards target capital structure: evidence from Indian companies", Journal of Advances in Management Research, 7(2), 250266.

35) Ozkan, A. (2001), “Determinants of capital structure and adjustment to long run target: evidence from UK company panel data", Journal of Business Finance \& Accounting, 28(1), 175198.

36) Ozkan, A. (2001), "Determinants of capital structure and adjustment to long run target: evidence from UK company panel data", Journal of Business Finance \& Accounting, 28(1), 175- 
198.

37) Öztekin, Ö., \& Flannery, M. J. (2012), "Institutional determinants of capital structure adjustment speeds", Journal of Financial Economics, 103(1), 88-112.

38) Tian, L., Han, L., \& Zhang, S. (2015), “Business life cycle and capital structure: evidence from Chinese manufacturing firms", China \& World Economy, 23(2), 22-39.

39) Titman,S., \& Wessels, R. (1988), "The determinants of capital structure choice", The Journal of finance, 43(1), 1-19.

40) Titman, S., \& Wessels, R. (1988), "The determinants of capital structure choice", The Journal of finance, 43(1), 1-19.

41) Tsoy, L., \& Heshmati, A. (2017). “Impact of Financial Crises on Dynamics of Capital Structure", Evidence from Korean Listed Companies.

42) Zhou, Q.,Tan, K. J. K., Faff, R., \& Zhu, Y. (2016), "Deviation from target capital structure, cost of equity and speed of adjustment", Journal of Corporate Finance, 39, 99-120. 